\title{
External Audit and Asymmetric Information Problem: Alternative Framework in Public Banking
}

\author{
Seda SÖNMEZ-ÖZEKICİOĞLU (https://orcid.org/0000-0001-9155-9480), Department of Banking and \\ Finance, Akdeniz University, Turkey; e-mail: sozekicioglu@akdeniz.edu.tr \\ Filiz YETIZ (https://orcid.org/0000-0001-5480-9268), Department of Banking and Finance, Akdeniz University, \\ Turkey; e-mail: filizyetiz@akdeniz.edu.tr

\section{Dış Denetim ve Asimetrik Bilgi Sorunsalı: Kamu Bankacılığında Alternatif Çerçeve}

\begin{abstract}
As an important policy instrument within the financial system, public banks assumed greater responsibility with the expansion of statist policies during the Great Depression of 1929. While maintaining and expanding its market share in the banking sector, Turkish Public Banking has undertaken the task of providing service for the benefit of the public and has increased its efforts to compete in global markets through the expansion of its customer portfolio - product range and financial innovations in information technologies lately. On the other hand, asymmetric information problem stemming from information pollution prevents the effective functioning of the audit mechanism, which is normally set to run based on accurate and complete information, and adversely affects the risk management processes of public banks. This study presents a proposal of an external audit model-"The Insured Customer-Based External Audit in Public Banking Model". The model proposed will contribute to the present financial system in terms of strengthening the legal power of the related institutions with the aim of reducing asymmetric information and increasing efficiency of external auditing in public banks. SWOT analysis has been conducted over the proposed model for greater understanding of its applicability and to reveal its possible effects in the banking sector. The results derived from the preferred method used in the study will pave way for the implementation of different numerical research methods in the future such as multi-criteria decision-making techniques in the same area of research.
\end{abstract}

Keywords $\quad$ : External Audit, Public External Audit, Court of Accounts, Independent External Audit, Asymmetric Information, Public Banking.

JEL Classification Codes : $\quad$ D82, G21, G28, M42.

\section{$\ddot{\mathbf{O} z}$}

Finansal sistemde maliye ve iktisat politikalarının önemli aracı olan kamu bankaları, 1929 Büyük Buhranıyla devletçilik politikalarının yaygınlaşması sonucunda önemli görevler üstlenmiştir. Piyasada pazar payını koruyarak genişlemekle birlikte kamusal fayda sağlama görevini üstlenen Türk kamu bankacıllğı, müşteri portföyünün - ürün yelpazesinin genişlemesi ve bilgi teknolojilerindeki finansal yeniliklerle küresel piyasalarda rekabet etme çabalarını artırmıştır. Diğer taraftan bilgi kirliliğinden kaynaklanan asimetrik bilgi sorunu, beraberinde doğru ve tam bilgiyle beslenen denetim mekanizmalarının etkin çalışmasını engelleyebilmekte; bankacılık sistemi içinde kamu bankalarının risk yönetim süreçlerinin kontrol ve denetimini zorlaştırabilmektedir. Çalışmada, kamu bankalarında asimetrik bilginin azaltılması ve dış denetimde etkinliğin artırılması amacıyla hukuksal yetkileri güçlendirebilecek ve mevcut sisteme katkı sağlayabilecek dış denetim modeli önerisi olarak "Kamu 
Bankacılığında Sigortalı Müşteri-Temelli Dış Denetim Model Önerisi” sunulmuştur. Model önerisinin uygulanabilirliğinde yöntem olarak SWOT analizi tercih edilmiş ve sektördeki muhtemel etkileri ortaya konularak literatüre yeni bir bakış açısı getirmesi amaçlanmıştır. Araştırmada olası sonuçları ile birlikte tercih edilen yöntem, çok değişkenli karar verme teknikleri gibi sayısal araştırma yöntemlerinin aynı konuda uygulanmasına örnek teşkil edecektir.

Anahtar Sözcükler : Dış Denetim, Kamu Dış Denetimi, Sayıştay, Bağımsız Dış Denetim, Asimetrik Bilgi, Kamu Bankacılığı.

\section{Introduction}

In the financial system, the banking sector interacts with both fiscal and monetary policies within the economic policies of the countries. Nonetheless, banks have crucial roles in public borrowing policies as the instruments of expansionary and contractionary fiscal policy. The banks' capabilities of maintaining their existence in effective, efficient and riskfree domains are important for the current and future of the financial structure in the country's economy. Along with the statist policies which emerged following the Great Depression of 1929 throughout the historical process, the presence of state-owned banks within the financial markets operating in the financial sector began to gain effectiveness. Nevertheless, the liberal policies that have been strengthened since the late 1970s have brought about a change and diversity in the structure of the banking sector along with private and foreign bank practices.

While these developments were taking place in the history, the risk factor in the banking sector became more and more evident, and finally became the focal point of the main problem in the 2008 Global Economic Crisis. The existence of asymmetric information in the banking sector has played a crucial role in encountering such a crisis, also known as the Mortgage Crisis. The banking sector is regulated and supervised to ensure a smoothly operating economy as well as the flow of funds to be dispersed to the most productive areas, especially during times of crisis. In order for the banking sector to operate effectively without risks and to maintain its activities by strengthening, it is of utmost importance to control the internal and external audit mechanisms and to mitigate the asymmetric information problem.

Banks play important roles in ensuring economic development and improvement, such as conducting intermediary duties in the financial sector, collecting deposits by providing liquidity to idle resources, borrowing loans, tackling asymmetric information problems, ensuring monetary stability, and creating deposit money. Public banks also loom large with their important duties within the financial system in balancing the awareness of the social responsibility and the economy they undertake while performing similar tasks along with other private and foreign banks in the sector. In this regard, the study aims to offer alternative solutions to the problems experienced in the public banking system, in response to the problems faced by addressing the issues of risk-oriented external audit and asymmetric information both on a global and country basis. 
In the study, which started out with the importance of external auditing in banking activities, the authority and responsibilities of the institutions and organizations involved in the external auditing mechanism in the banking sector are handled within the current legislative information. The study is formalized by the experience of the asymmetric information problem in the banking sector and detailed with possible advantages and disadvantages. It is aimed at contributing to the related literature by courtesy of efficiently functioning external audit mechanism through the model proposal and the SWOT analysis presented to reduce asymmetric information in banking.

\section{The Position of External Audit within Banking Operations}

The banking system is subjected to various regulations and controls in order to ensure that the flow of funds of banks is realized in the most appropriate manner. Along with the efficient control mechanisms in the banking system, it is aimed to make banks operate more efficiently by minimizing the errors in applications, the risks encountered, and the financial crisis. The sound and efficient banking system, on the other hand, facilitates the protection of savers from risks and helps entrepreneurs to make investments, but also increases economic growth (Rioja \& Valev, 2004: 127). It has been observed that the vast majority of the financial issues in the banking sector originates from insufficient audit systems, and some banks have been deprived of their reputation due to the ineffectiveness of their control mechanisms. Therefore, the supervision and regulation of the banking system are of utmost importance for the affirmative contribution of the sector to economic growth.

While trust in banks within the financial system positively reflects the formation of a stable domain in the economy, insecurity lays the groundwork for an unstable domain (Altay, 2006: 49). Auditing is vital for the control and effective maintenance of banking activities. Banks encounter various risks such as credit risk, operational risk, interest rate risk, country risk, and exchange rate risk (Gündoğdu, 2016: 387). A powerful audit mechanism is needed to mitigate these risks that may result in banking crises and bankruptcy and to detect all the mistakes that may stem from the faulty banking transactions. In this context, international auditing, internal auditing and external auditing mechanisms are used in the banking sector.

The main objective of auditing in the banking sector is to ensure that banks have sufficient capital by minimizing their risks and to establish trust in the financial sector. In the banking system, auditing takes place under the name of internal audit and external audit through the process of examining and evaluating the financial records of banks within three or six months, or 1 year, by authorized persons from within or outside (Okur, 2010: 158). Internal audit is performed by internal auditors consisting of individuals who perform audit activities within the organization and is conducted through an independent auditing unit within the organization to review, evaluate and monitor the activities of the organization (Bozkurt, 2001: 33). External audit, which operates in cooperation with internal audit, is conducted by auditors who are not employed by the institution, and it is carried out as independent audit and public audit (Güney \& Sar1, 2015: 67). As depicted in Figure 1, the external audit within the banking system is conducted in two different areas of expertise. 
Figure: 1

\section{Types of External Audit in Banks}

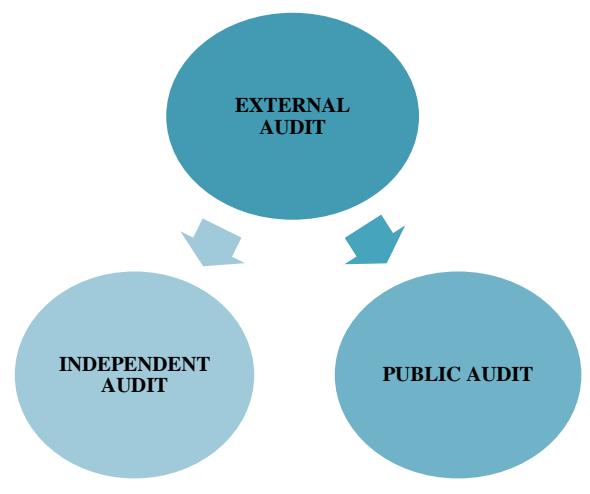

Within the scope of determining and evaluating risks in banking; an imperative, an imperious and a public side loom large in the external audit, which is conducted mainly within the framework of legal regulations (Erol \& Ertuğrul, 2001: 31). An independent audit involves an auditing process in which financial statements of financial institutions are audited by experts working under an auditing firm (Oktay, 2013: 44). Public audit, on the other hand, is a type of external audit in which financial statements, compliance and performance audits that assume their authority from the law and perform audits on behalf of the public are conducted (Ataman, 2010: 19).

Although the internal auditing mechanism, besides external auditing types, has to operate with the same objectivity and independent spirit in the banking sector, in some cases, unforeseen problems may occur. Banks are also audited by authorized institutions and organizations within their external audit processes in order to eliminate the severe consequences of such problems that may have adverse impacts on the financial sector (Gündoğdu, 2016: 413). The positive opinions in the reports of the external auditors, who conduct external auditing activities candidly and independently, increase confidence in the banking sector. Furthermore, the complex increase in banking sector activities at the national and international level also renders the tasks of external auditors of the banks more demanding (Siddiqui \& Podder, 2002: 504).

In addition to the activities of commercial banks such as deposit transactions, credit transactions, foreign exchange transactions, repo transactions, insurance brokerage transactions, and fund transactions; transactions specific to participation banking are also conducted both on national and international scales. Along with the transaction and product range of the banks, the diversity and volume of customers also increase. Asymmetric information including adverse selection, moral hazard and principal-agent problems between banks and customers in different profiles can be experienced even more as of today compared to the past. Effective operation of risk-oriented external audit mechanisms, which 
cooperate with the internal audit mechanisms of banks, are of great importance in mitigating and eliminating asymmetric information-based problems.

\subsection{Overview of External Auditing in Public Banking Sector}

There are certain crucial issues to be taken into account in order for organizations using public resources to have an effective external auditing mechanism. The first one involves the fact that the external auditing mechanism operates independently from the influence of any external factor and is supported by law. In this context, the external auditors, who conduct their external auditing activities, should be able to perform and report their performance audits beyond any reasonable doubt. Another important issue involves the fact that all revenues, expenses, assets, and liabilities of the institution must be covered by external auditing. Consequently, the external auditors have the technical and professional abilities to conduct the external auditing process and receive support from other experts whenever deemed necessary (INTOSAI, 1998: 1-7).

Public banks, which assume a mediatory role for the state to perform its regulatory duties within the financial system, are distinguished from private and/or foreign banks in terms of their duties and priorities. In order to ensure efficient, economical and effective utilization of scarce public resources through public banks which set social or public benefits and country interests as priorities and offer banking activities with their public identity; both internal and external auditing mechanisms have distinctive merits.

The external auditing, which has a risk-oriented audit approach, affirmatively influences the conduct of the audit. Nonetheless, there are some issues to be considered in the conduct of an audit. The first of these problems is the expectation gap; the second, the uncertainties surrounding the auditor's responsibilities; the third is the problem of providing reasonable assurance, and the fourth is the practical implementation of audit standards. The concept of "expectation gap", as one of the leading problems of external audit that was first coined by Liggio (1974) in the literature, involves the expectational differences in terms of external audit between external auditors and those who use financial statements (companies, bankers, etc.) (Prinsloo, 2008: 3).

Regarding the mitigation of expectation gap in external audit, Litjens et al. (2015) conducted a survey study in the Netherlands with 302 participants (61 bankers, 118 preparers and 123 auditors). As a result of the study, it was detected that the bankers needed additional information from the external auditors about their current and potential customers in order to reduce the asymmetric information; the managers were reluctant to share sensitive information about their customers with external auditors; and external auditors strived to reduce their risks within the scope of the risk-oriented audit approach. In the study, it was also found that reporting the errors detected during the financial audits of the customers by the external auditors reduced the expectation gap of the bankers.

The second problem in external audit involves an intervention in the responsibilities of external auditors within the objectives of external audit that change over time and a 
depature from the essence of external audit. The third problem arises in the context of the risk-oriented audit approach that external audit has to work as a whole to provide reasonable assurance that the financial statements do not contain material misstatements. At this point, in external audit, reasonable assurance is less than $100 \%$ assurance, but it should be sufficient and appropriate audit evidence. Fourthly, the problems faced by risk-oriented external audit in practice serve as proofs of how complicated this profession would be (Prinsloo, 2008: 3-12).

\subsection{Legislative Position of External Audit Institutions in Public Banking Sector}

Public banks in Turkey are considered within the scope of the "State Economic Enterprises" mentioned in the Article 165 of the 1982 Constitution and the Article 4 of Audit Court Law No. $6085^{1}$ and the auditing process is implemented in accordance with the Article 43 of Audit Court Law No. 6085. External audit of the public banks is conducted by the Turkish within the scope of Article 2 of Law No. 3346 on Arrangement of Auditing of State Economic Enterprises and Funds by the Turkish Grand National Assembly, and the Turkish Court of Accounts provides the commission with technical support. Moreover, the Turkish Court of Accounts makes general evaluations for public banks with the annually prepared External Audit General Evaluation Report; it also includes the end-period financial position of public banks in the Public Enterprises General Report.

The Central Bank of the Republic of Turkey (CBRT) conducts regulatory and supervisory functions towards the financial system by using monetary policy tools within the scope of the principles such as independence, transparency, and accountability, reliability, protecting the public interest, efficiency, and effectiveness with the authorization received from the CBRT Law No. 1211. The CBRT, whose main objective is to ensure price stability, is authorized to solve the problems that may arise in the money and capital markets and to control the sector by directing the operation of the banks as the most crucial part of the financial system, within the scope of monetary policy objectives. As indicated in Article 43 of the CBRT Law No. 12112 "All banks, special finance houses, and other financial institutions deemed appropriate by the Bank, operating in Turkey shall be obliged to submit their annual balance sheets and income statements along with the reports of their boards of directors and that of auditors to the Bank, at the latest within one month, after their general assembly meetings and the reports of independent auditing institutions after the date of preparation" (as amended by Law No. 4651, dated 25.04.2001 and Article 43 of the CBRT Law No. 1211). It is clearly stated that all banks, including public banks, have the authority to request balance sheets and reports within the scope of external audit.

1 “The Turkish Court of Accounts, Law No. 6085”, dated 03.12.2010, Official Gazette.

2 "The Central Bank of the Republic of Turkey, Law No. 1211", dated 14.01.1970, Official Gazette. 
The Banking Regulation and Supervision Agency (BRSA) was established under the Banking Law No. 4389; operating as an autonomous institution within the framework of supervisory and monitory authority over banks under Law No. 54113 adopted on 19.10.2005. Within the scope of the Banking Law No. 5411, it is stated that public banks are subject to external audits of the BRSA. According to Article 37 of the same law, the BRSA's obligations in the field of external auditing, including public banks and other banks, are presented in Table 1 below:

Table: 1

\section{External Audit Authority of the BRSA}

- In compliance with the principles and procedures to be established by the Board upon consulting the associations of institutions and the Turkish Accounting Standards Board taking international standards into consideration, ensure uniformity in their accounting systems;

- To account records correctly for all their transactions;

- Timely and correctly prepare their financial reports in a manner that meets the requirements of providing information, that is clear, reliable and comparable, and that is appropriate for auditing, analysis, and interpretation.

Source: Article 37 of the Banking Law No. 5411, dated 19.10.2005.

Within the scope of Article 37 of the Banking Law No. 5411, the BRSA can take some measures in line with its duties and authorities while performing its external auditing functions on public banks. Upon encountering erroneous information while conducting the audit on the financial statements, the external audit institution is authorized to take measures within the scope of correction of such information. Within the scope of external audit obligations, the period of time that the public banks would be audited by the BRSA tends to vary on a per bank basis. The main reason for the difference lies in the size, risk structures, financial complexity and diversity of the banks to be audited. After the public banks are audited, a rating grade is created, indicating the bank's risk score.

The BRSA can use two distinct methods that complement each other in the form of on-site audits and surveillance while conducting auditing activities on public banks. While public banks go through one-to-one on-site audit processes, the analyses are made on the bank's receivables, assets, liabilities, profit or loss situation, own resources, compliance of the records in its financial statements with accounting principles, confidence in information systems, competence of management quality, and adequacy of internal control mechanisms. In the supervisory activities, it is tried to be measured in various ways by monitoring the financial developments of the public banks within the sector, stress tests, monitoring the rating notes by taking into account the results of the previously conducted on-site auditing activities, early warning systems and the timely analysis of the change in financial structure and performance, and whether or not a violation of the legislation exists (BRSA, 2019).

Another one of the institutions authorized in external audit is the Savings Deposit Insurance Fund (SDIF). Although the institution was run by the CBRT in the early years of its establishment, its representation and administration were transferred to the BRSA in the 
following periods. The increase in the number of banks that collapsed after the financial crises in the 2000s made a great contribution to the SDIF in becoming an autonomous institution. The SDIF conducts its external auditing activities on banks within the context of the Banking Law No. 5411, the Law No. 6758 on the Taking of Some Measures in the Context of the State of Emergency, and other relevant legislation. Some of the important duties of the SDIF in external auditing on public banks within the framework of relevant laws and regulations include insurance of the saving deposits within public banks and participation funds of real persons, mitigation of existing banking defects, restructuring and strengthening financial structures, and monitoring and collection of fund receivables. Another important task of the SDIF is the payment of deposit and participation funds of the banks whose financial structure has been impaired and decided to be transferred to the SDIF by the BRSA (Banking Law, Article 63). The management and supervision of banks whose operating permissions are revoked as a result of the audit conducted by the BRSA are transferred to the SDIF. The SDIF is authorized on transferring, selling or merging of the banks, partially or fully, on the condition that the loss will be deducted from the capital of the existing partners (Banking Law, Article 71).

Consequently, the SDIF's authority on the external audit of public banks involves the transfer of the deposits, participation funds, bailed goods and receivables in public banks specified in Article 62 of the Banking Law No. 5411. The SDIF is authorized to conduct transactions pursuant to Article 8 of the "Regulation on Principles and Procedures regarding Collection and Prosecution of the Receivables of the Savings Deposit Insurance Fund" No. 26396. ${ }^{4}$ In Table 2, the tasks and responsibilities of the external audit institutions during the supervision of public banks in Turkey are summarized along with the relevant legal legislation.

Table: 2

\section{Place of External Audit Institutions during the Supervision of Public Banks in Turkey}

\begin{tabular}{|c|c|c|}
\hline External Audit Establishment & Legislative Description & Authority and Responsibility in External Audit \\
\hline Turkish Court of Accounts & Law No. 6085 & $\begin{array}{l}\text { Article } 4 \text { - Clause } 3 \\
\text { Article } 43\end{array}$ \\
\hline Turkish Grand National Assembly & Law No. 3346 & Article 2 \\
\hline CBRT (Central Bank of the Republic of Turkey) & Law No. 1211 & Article 43 \\
\hline BRSA (Banking Regulation and Supervision Agency) & Law No. 5411 & $\begin{array}{l}\text { Article } 37 \\
\text { Article } 65\end{array}$ \\
\hline \multirow[t]{2}{*}{ SDIF (Savings Deposit Insurance Fund) } & Law No. 5411 & $\begin{array}{l}\text { Article } 62 \\
\text { Article } 63 \\
\text { Article } 71\end{array}$ \\
\hline & SDIF Legislation / Regulation No. 26396 & Article 8 \\
\hline $\begin{array}{l}\text { The Banks Association of Turkey \& } \\
\text { The Participation Banks Association of Turkey }\end{array}$ & Law No. 5411 & $\begin{array}{l}\text { Article } 79 \\
\text { Article } 80\end{array}$ \\
\hline Ministry of Treasury and Finance & Presidential Decree No. 30474 & Section 7 - Article 217 \\
\hline CMB (Capital Markets Board) & Law No. 6362 & Article 1 \\
\hline \multirow{2}{*}{ Independent Audit Institutions } & Regulation No. 27461 & Articles 1-45 \\
\hline & Law No. 5411 & Article 97 \\
\hline
\end{tabular}


Among all organizations that undertake important tasks of external audit mechanisms, the Banks Association of Turkey (BAT) and the Participation Banks Association of Turkey (PBAT) are in support of the functioning of the mechanism. These associations are among the important institutions that enable the banking sector to be developed in a global environment and strengthened in financial areas. All public, foreign, and private deposit banks, development banks, and investment banks operating in Turkey which must become members of the Banks Association of Turkey; whereas Participation banks must become members of the Participation Banks Association of Turkey within one month following the date of receipt of their operating permissions (Banking Law No. 5411, Article 79). The duties and authorities of the BAT and PBAT are specified in Article 80 of the Banking Law No. 5411 and it is observed that the auditing activities of the associations on public banks are implemented in accordance with the duties and authorities specified in the related article. In this context, the duties and authorities of BAT and PBAT in support of the external auditing mechanism include protecting the rights and interests of public banks as well as other banks in the sector; development of the banking profession; enlarging the banking system and ensuring its sound operation; ensuring cooperation among banks on joint projects; taking necessary measures to maintain competitiveness in the sector, and to prevent unfair competition.

The Undersecretariat of Treasury and the Ministry of Finance were merged with the Presidential Decree No. $1^{5}$ published in the Official Gazette No. 30474 in 2018 and began to operate under a single roof known as the "Ministry of Treasury and Finance". The main duties of the Ministry are determined by Article 217 of Section 7 of the relevant Decree. Within the scope of the related article, it is seen that these parts of the duties and authorities that involve conducting studies to determine the basic policies and strategies regarding tax inspection and auditing; organizing activities related to the exchange regime and monitoring practices; determining the principles for preventing money laundering; participation in activities of public institutions and organizations, including economic policies; transactions related to public financing, borrowing and granting from public institutions and enterprises also cover public banks, especially in external audit practices.

The Capital Markets Board (CMB) uses its duties and authorities within the framework of the Capital Markets Law No. $6362^{6}$ in order to ensure the safe operation of capital markets. The aim of this Law is emphasized in its Article 1; “...to regulate and supervise capital markets to ensure the functioning and development of capital markets in a secure, transparent, efficient, stable, fair and competitive environment and to protect the rights and interests of investors." As of today, it is seen that banks tend to head for capital markets in order to provide resources beyond the typical banking activities. In the sector,

\footnotetext{
5 "Presidential Decree on the Presidential Organization, Presidential Decree No.1", dated 10.07.2018, Official Gazette.

6 "Law on Capital Markets, Law No.6362", dated 30.12.2012, Official Gazette.
} 
which also includes public banks, banks become public stock corporations by offering their shares to the public. This circumstance brings forth the responsibility of banks to become transparent and to provide the public with information. Thus, the reliability, comprehensibility, and comparability of information become crucial. Risks that arise, if the information is unreliable, may spread to other banks in the sector and cause larger financial crises. This situation indicates that public banks have an obligation to inform the public according to the capital market law. In this context, in order to reduce the asymmetric information problem, the CMB is responsible for maintaining the efficient and effective operation of the markets.

Independent Supervisory Institutions are other authorized bodies that play a role in the supervision of public banks' banking transactions, besides the public institutions responsible for external audits in accordance with the legislation. Independent audit activities in public banks are conducted through independent external audit firms authorized by the BRSA (Yazic1, 2015: 128). The scope of the Independent Supervisory Institutions responsible for external auditing of banks has been regulated within the scope of the "Regulation on Authorization and Activities of the Institutions to Perform Audit in Banks" published in 2006. The framework of the external audit is explained in detail within the scope of the Regulation on Bank Information Systems and Banking Processes Audit to be Performed by External Audit Institutions numbered $27461^{7}$ and the Audit of Banking Processes, which came into force in the following years. In Articles 1 and 2 of the Regulation; the purpose, scope, procedures, and principles of the audit are specified by the independent supervisory institutions assigned in the banking processes, including public banks. The regulation consists of 45 articles, and various issues such as the importance, effectiveness, adequacy, audit risk, the conditions sought in the institutions that will be authorized in the independent supervision, and the definition of the supervisory authority are clearly described.

Within the scope of Article 97 of the Banking Law No. 5411, it is essential that banks, including public banks, undergo independent auditing processes four times a year (quarterly audit) and publicize the audited financial statements. In the light of current data, totally 44 independent auditing firms authorized by the BRSA (37 of which are in in the field of financial auditing and 7 of which are in the field of information systems auditing) actively carry out their activities in the field of external auditing (BRSA, 2019).

\section{Asymmetric Information Problem and Experiences in Banking Sector}

The asymmetric information problem encountered in the banking sector, especially in the credit market, arises in two ways, namely; moral hazard and adverse selection. It is an adverse selection problem if a bank's customer, being aware of the fact that the probability 
of repaying the loan borrowed from the banks is very low, accepts to pay a very high-interest rate to the bank in return for the loan. It is moral hazard if a loan borrower who is responsible for the repayment of the loan raises difficulties in repaying the loan, deliberately fails to repay the loan when he/she has the means to do so or engages in certain activities that are thought to be undesirable or unethical (Mishkin, 1997: 56-57). Consequently, conflicts of interest arising from asymmetric information between lending financial institutions and loan borrowers lead to risky transactions or reduction of the use of funding resources provided by financial institutions (Şahin, 2012: 4-5).

\subsection{Asymmetric Information Problem and Its Reflections on Banking Sector}

Banks, which are an important element of the financial system, fulfil the function of transferring funds to individuals or companies with effective investment opportunities by collecting and processing information. Although the institutions within the financial system deal with a large amount of information; a certain portion of the information contains asymmetric information by nature. In other words, the lending party in the financial contract may have less accurate information about the possible distribution of the outcomes than the other party, the borrower. Throughout the historical process, banks and other financial intermediaries play major roles in reducing asymmetric information including adverse selection, moral hazard and / or agent-principal problems (Mishkin, 2009: 3).

Asymmetric information is based on the "Lemon Market" theory, originally introduced by G. Akerlof (1970), stemming from the incomplete dissemination of information between supply and demand. Asymmetric information also feeds on behavioural patterns and uncertainties that are far from honesty, causing a moral hazard, principal-agent, and adverse selection problems. In the banking sector, depositors strive to eliminate the disadvantaged position of borrowers (real/legal person) in accessing information by leaving the task of collecting and processing information about credit ratings to bank employees. Nonetheless, this time, the banking personnel have a disadvantage toward the top management of the bank (Akerlof, 1970: 498-499). It is crucial to increase the product quality in the banking sector, to minimize the costs, to maintain the trust environment in the banking sector within the national and international arena, and to mitigate all asymmetric information problems by defining them clearly. In this context, the external auditasymmetric information problem should be handled simultaneously in the banking sector and alternative solutions should be proposed for practical problems.

Although occasional uneven dispersion of the information in the financial markets to the owners of investments and savings influences the decision-making processes, it also hinders the sound functioning of the markets. The asymmetric information problem frequently encountered in credit markets within the banking system weakens the efficiency level of financial markets. It is possible for banks to determine the best and accurate price for depositors who would apply for credit in loan allocation processes by acquiring complete and accurate information regarding the company to be credited. Incorrect credit decisions and moral hazard made during the pre-control and evaluation processes lead to credit rationing. Credit rationing narrows the financing opportunities of projects that are efficient 
in the economy, hence, financial stability is impaired and economic growth is adversely affected. There are distinct solutions to mitigate the impacts of the asymmetric information problem on credit markets. In this context, the formation and use of asymmetric information can be prevented by market regulations. Along with the arrangements to be made, the information in the financial statements to be prepared by the companies should acquire certain standards, and such information should be fully and accurately disclosed. As a result of an unbiased audit and legal arrangements, information differentiation in credit markets may cease to exist (Müslümov \& Aras, 2004: 55-65).

\subsection{Current Practices of Asymmetric Information Problem in Turkish Public Banking Sector}

The existence of asymmetric information in Turkish public banking sector can sometimes render the sector advantageous and as well as disadvantageous. Asymmetric information narrows the market shares of public banks in the sector and weakens their effectiveness in the market, especially under competitive conditions. Table 3 contains a summary of the advantages and disadvantages of asymmetric information in the public banking sector.

Table: 3

\section{Advantages and Disadvantages of Asymmetric Information in the Public Banking} Sector

\begin{tabular}{|c|c|}
\hline Advantages & Disadvantages \\
\hline - Gaining a ready customer base & $\begin{array}{l}\text { - The ratio of rejected loans that may be risky would be lower } \\
\text { - The risky customer ratio in the total customer portfolio may } \\
\text { increase }\end{array}$ \\
\hline - The priority demand by new customers in the market along with the confidence of being a public bank & $\begin{array}{l}\text { - Uncertainty of the work ethics of the new customer in bank } \\
\text { activities } \\
\text { - Lack of sufficient information regarding the morality* of the new } \\
\text { customers: moral hazard problem } \\
\text { - An adverse selection problem may arise along with increase the } \\
\text { risk factor due to having new customers }\end{array}$ \\
\hline $\begin{array}{l}\text { - Increased continuity of the bank's association with the permanent customer base within an } \\
\text { environment of trust }\end{array}$ & $\begin{array}{l}\text { - The bank's credit management risk may rise during periods of } \\
\text { sectoral contraction in the market. } \\
\text { - The financial risks of permanent customers may be assumed in } \\
\text { times of economic crisis }\end{array}$ \\
\hline - Being the primarily preferred by highly credible customers in the sector & $\begin{array}{l}\text { - The credibility of the customers that can be weakened due to } \\
\text { unforeseen risks }\end{array}$ \\
\hline $\begin{array}{l}\text { - Minimized principal-agent problem by courtesy of detailed risk-oriented control mechanism in public } \\
\text { banks }\end{array}$ & $\begin{array}{l}\text { - Loss of time in responding to urgent customer needs and failure } \\
\text { to meet potential and / or permanent customer demands }\end{array}$ \\
\hline $\begin{array}{l}\text { - Reinforcement of economic growth and development by providing sectors that favorably support } \\
\text { economic and budgetary policies with privileged facilities in banking activities }\end{array}$ & $\begin{array}{l}\text { - Risk management problem caused by the intense credits allocated } \\
\text { to the sectors at near proximity to public banks } \\
\text { - The problems that may be caused by the sectoral contraction } \\
\text { accompanied by unforeseen risks can be reflected on the bank's } \\
\text { activities }\end{array}$ \\
\hline $\begin{array}{l}\text { - Expanding its product range and gaining new customers as a result of providing government- } \\
\text { supported projects with financial intermediation services }\end{array}$ & - The problem of encounter risky customers \\
\hline $\begin{array}{l}\text { - As required by state policy, the range of customers may expand due to the transfer of risky banks to } \\
\text { public banks; technology and system infrastructure of the transferred banks; trained personnel transfer } \\
\text { can take place }\end{array}$ & $\begin{array}{l}\text { The obligation of a public bank to operate at the first stage with } \\
\text { its current risky customer portfolio. } \\
\text { - Having to manage risky loans } \\
\text { - The problem of compliance with corporate identity in personnel } \\
\text { transfer } \\
\text { - Increased overheads (workload, staff salaries, and career training } \\
\text { costs) in public banks }\end{array}$ \\
\hline
\end{tabular}


In addition to the information presented in Table 3, for instance, agricultural loans (as positive contributions to economic growth) to be lent by public banks may be considered as a requirement of social responsibility policies. On the other hand, although agricultural loans are considered as a high-risk factor product group for public banks, they are provided by public banks in line with economic and social benefits (Stiglitz \& Weiss, 1981: 407). In order to mitigate the experience of all these asymmetric information-based problems by public banks with an efficient external audit system, the external model proposal, and solution-oriented evaluations are included in the last part of the study.

\section{A Model Proposal for Public Banking: A SWOT Analysis}

Within the constantly competitive globalized financial system and developing banking sector, public banks wish to capture a large share from the market in the total banking sector by increasing their profitability along with controlled expansion and efficiency. As public banks progress, it becomes difficult to control and supervise them and accordingly, new applications are required in their audit processes. Important tasks devolve on external audit mechanisms that operate in coordination with the internal audit processes containing complete and clear information throughout this process. By courtesy of the external audit mechanisms, which began to operate effectively by minimizing the asymmetric information problem, the public banking system may have brought many affirmative improvements to the entire banking sector with its own structure.

In the study, the solution methods for the existing external audit and asymmetric information problems of the public banks as well as the new external audit model proposal, namely, "The Insured Customer-Based External Audit in Public Banking Model Proposal" are depicted by Figure 2.

The size, specialization areas, branch structures and numbers of public banks tend to differ due to their fields of activity. In the public banking sector, where such differences exist, external audit activities may differ from each other. Along with these facts, "The Insured Customer-Based External Audit in Public Banking Model Proposal" is generated based on insurance which aims at reducing asymmetric information within bank-customer relationships and strengthening the social benefit mission by bringing customers from different risk groups into the bank portfolio. Public/private insurance companies assume the responsibility of ensuring the customer's financial and fiscal data and presenting a truly global data coverage to all external auditing institutions and organizations as the key actors in the model proposal. The Qualitative SWOT matrix is presented in Table 4 to test the applicability of the model proposal with a research technique. The size, specialization areas, branch structures and numbers of public banks tend to differ due to their fields of activity. In the public banking sector, where such differences exist, external audit activities are also likely to differ from each other. Considering this fact, "The Insured Customer-Based External Audit in Public Banking Model Proposal", based on insurance is evaluated in Table 4 via the SWOT analysis. 
Figure: 2

The Insured Customer-Based External Audit in Public Banking Model Proposal

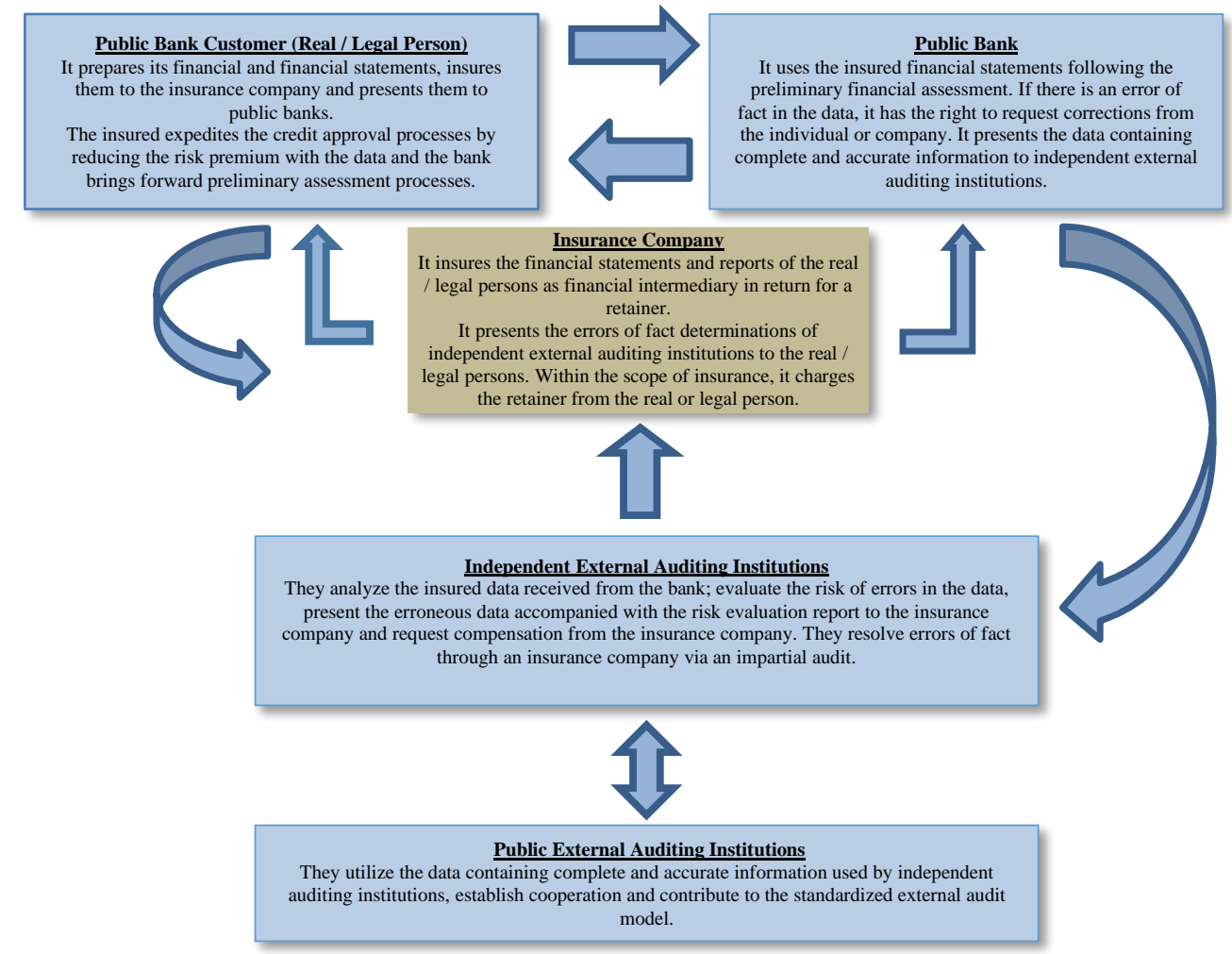

Source: "The Insured Customer-Based External Audit in Public Banking Model Proposal" was created by the authors of the study.

\subsection{Aim of the Research Study}

This research study aims to demonstrate the applicability of "The Insured CustomerBased External Audit in Public Banking Model Proposal", which is developed to mitigate the asymmetric information problem experienced in public banking and to promote efficiency in external audit, via SWOT analysis method.

\subsection{The Methodology of the Research Study}

The data associated with the model proposal considered in the research study is evaluated within the framework of the qualitative research technique. In the evaluations, the brainstorming method participated by external audit and public banking expert interviewers is utilized and participated. Accordingly, the findings of the research study are detailed with the SWOT analysis in the context of four subcriteria. 


\subsection{Findings of the Research Study}

The SWOT matrix method used in the research study is based on the studies conducted by A. Humphrey, R. Stewart, M. Dosher, O. Benepe and B. Lie in the Stanford Research Institute (SRI) International over the period between 1960-1970. The research was funded by the Fortune 500 companies to find out what had gone wrong with corporate planning and to create a new system for managing change. In the conducted research study, survey questionnaires consisting of 250 questions were tested on more than 5,000 managers employed by 1,100 organizations (Humphrey, 2005: 7). The SWOT framework was first described in detail in the late 1960s by Edmund P. Learned, C. Roland Christiansen, Kenneth Andrews, and William D. Guth (Learned et al., 1969).

The SWOT analysis is conducted by considering the associated strengths and weaknesses of "The Insured Customer-Based External Audit in Public Banking Model Proposal". Also, possible opportunities and threats are also discussed as external factors. The SWOT matrix is given below;

Table: 4

A Qualitative SWOT Matrix for the Model Proposal: List of Key Issues

\begin{tabular}{|c|c|c|}
\hline Factors & Enhancers & Inhibitors \\
\hline \multirow{3}{*}{ 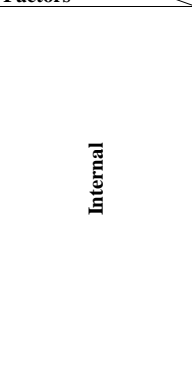 } & Strengths & Weaknesses \\
\hline & $\begin{array}{l}\text { - Translocating public banking into a locomotive and leading } \\
\text { position in the sector regarding credit volume } \\
\text { - Sharing responsibility with insurance companies in } \\
\text { managing risky and bad loans } \\
\text { - Bringing public banking to an impervious, strong and } \\
\text { dynamic structure with a risk-oriented management process } \\
\text { - Supporting the applicability of transparent, reliable, and } \\
\text { objective external audit norms in the entire public banking } \\
\text { sector } \\
\text { - Supporting collaboration between public audit and } \\
\text { independent audit firms in external audit } \\
\text { - Constituting a truly global data coverage within the external } \\
\text { audit field }\end{array}$ & $\begin{array}{l}\text { - Increasing the current and investment costs of banks by } \\
\text { forming supplementary budgets in public banks } \\
\text { - Personnel training costs in the adaptation phase of the } \\
\text { model } \\
\text { - Including new management and administrative units to } \\
\text { support the implementation of the model in the } \\
\text { organizational structure of the bank. } \\
\text { - The need for qualified personnel who can operate in newly } \\
\text { established units. }\end{array}$ \\
\hline & Opportunities & Threats \\
\hline 㺼 & $\begin{array}{l}\text { - Mitigating asymmetric information problems between } \\
\text { customer and bank in external auditing by means of truly } \\
\text { global data coverage } \\
\text { - Bringing the potentially poor customer portfolio into the } \\
\text { system in a controlled manner and reducing the exclusion } \\
\text { effect. } \\
\text { - Setting an example for private, foreign and/or other banks } \\
\text { with foreign partners, and the possibility of similar models } \\
\text { to be designed }\end{array}$ & $\begin{array}{l}\text { - Posing the risk of not using scarce public resources within } \\
\text { the context of } 3 \mathrm{E} \text { (Efficiency-Economy-Effectiveness) } \\
\text { - Creating opportunity costs by increasing IT and additional } \\
\text { investment expenses } \\
\text { - Resulting in unfair competition by narrowing the market } \\
\text { share of customer portfolio in the banking sector compared } \\
\text { to other banks. } \\
\text { - Ability to jostle the foundations of public banking in the } \\
\text { sector as a result of the prolongations in the adaptation } \\
\text { process during the application of the model proposal to the } \\
\text { sector. }\end{array}$ \\
\hline
\end{tabular}

Source: Table 4 was created by the authors of the study via using interview notes.

\subsection{Impacts of the Research Study}

The evaluations obtained with the SWOT matrix used in the study also include the direct and indirect potential impacts of "The Insured Customer-Based External Audit in Public Banking Model Proposal". The first of these impacts is that the model proposal for the entire banking sector can be an important road map for both public banks as well as 
private and foreign banks. External audit, whose efficiency has increased with the model proposal, can boost the power of public banks and the banking sector not only in national but also in international competition. The model proposal has another possible impact on banking transactions. In this context; the model proposal, by which public banks that provide public benefits besides taking risks and having to manage current and potential risks, can facilitate banking transactions.

Another possible impact of the model proposal involves the long-term positive reflection of the cooperation between the public auditing and the independent external auditing institutions, which is included in the SWOT matrix as one of the strengths. The existence of coordinated or simultaneously operating public auditing and independent external auditing institutions may support the public banking system to attain a stronger, more dynamic and sector-resistant structure. By courtesy of the legal enforcement of external auditing institutions, it would be possible to channel resources in the public banking sector toward more efficient areas and to reduce the transactions that are considered to be risky, thereby achieving cost efficiency.

The contribution of truly global data coverage, which can be developed with the model proposal, to the public banking external audit process constitutes another crucial potential impact of the research study. It is among the objectives of the model proposal to be selective in the data collected by independent and public external auditing institutions during the external audit and to prepare external audit reports that include solutions (reducing costs-increasing benefits) in order to achieve the goals.

Based on the technological developments in the industry 5.0 era, the model proposal may provide positive impacts for the external audit mechanism in public banking, shortening business cycles, enabling easy access to complete and accurate information, and facilitating processes by standardizing external audit transactions. Besides these potential impacts, the model proposal can be considered as a crucial project in terms of increasing efficiency and effectiveness during external auditing in public banking.

As a macro-scale impact of the model proposal, public resources may be withdrawn from idle, risky and inefficient banking areas and resource waste can be prevented. In this case, a stable comprehension of public banking, which can support the increase of savings in the economy and act in compliance with economic policy objectives, may have strengthened its position in the sector.

\section{Conclusion and Evaluations}

The banking sector, as a key component of the financial sector in global economies, is one of the most important instruments of monetary and fiscal policies, both nationally and internationally. The public banking sector contributes positively to economic growth and development with the social and economic benefits it creates within the banking market share. In this context, mechanisms can be developed to support existing external auditing processes to mitigate asymmetric information problems so that their contributions may 
continue increasingly, and public banking can operate more effectively, efficiently and economically.

As a result of increased banking activities and customer diversity, each of the public, foreign and private banks establish risk assessment units to mitigate asymmetric information by themselves and develop different risk measurement programs and computer software. The aim is to minimize risks of the bank by working with customers having high morality and low risk premium by courtesy of complete and accurate information. However, since the common attitude of banks toward risk can sometimes be subject change periodically, the customer risk measurement and management software's used by each bank to reduce asymmetric information may also differ. In this study, "The Insured Customer-Based External Audit in Public Banking Model Proposal" developed for public banks can be expanded by including private and foreign banks in the following phases, and a customer information network can be generated with standardized software programs in national and international scales.

In this study, by examining the position and duties of external auditing institutions and organizations in legal legislation in public banking, the principles of both public and independent external auditing within the framework of existing external audit mechanisms are considered. In the study; the asymmetric information problem is addressed along with its advantages and disadvantages in public banking, "The Insured Customer-Based External Audit in Public Banking Model Proposal" is introduced to reduce the uncertainties and negativities caused by the asymmetric information in the sector's efficiently-functioning external audit mechanism. In the qualitative SWOT analysis, the model proposal is evaluated with its strengths, weaknesses, opportunities, and threats, which are among the environmental external evaluation criteria.

It is crucial in terms of the acceptability of the model to develop state policies in the SWOT analysis that can transform performance criteria from inhibitors into enhancers and to include auxiliary budget policies to offset the initial costs. On the other hand, weaknesses of internal factors within the institution can be transformed into investment instruments that feed long-term strengths, although they include the short-term and temporary expenditures that may be incurred throughout the application phase of the model. In order to minimize the potential threats and promote the opportunities, which are evaluated as external factors of the model proposal, the state bodies can make contributions to facilitate the applicability of the model with both legislative arrangements and pilot region implementations.

In conclusion, the model proposal, developed on the basis of the direct/indirect and micro/macro scale impacts based on the findings of the research, creates an alternative framework in terms of bringing it to the industry in practice and the literature. The model proposal that mitigates the uncertainties and adverse impacts of asymmetric information on public banking, supports effective external auditing and includes insurance companies in the system with its intermediary role, also elicits a radical innovation in the existing banking system. The contribution of the model proposal to the literature involves the fact that the 
model has an originality that can set an example for numerical research methods such as multi-criteria decision-making techniques while deciding on its implementation.

\section{References}

Altay, N.O. (2006), Türk Bankacılı Sistemi, Ege Üniversitesi İktisadi ve İdari Bilimler Fakültesi, Yayın No: 5, İzmir, Türkiye.

Ataman, B. (2010), “Türkiye’de Kamu Denetimi ve Kamu Denetçilerine Genel Bir Bakış”, Maliye Finans Yazıları, 1(87), 17-26.

Bozkurt, N. (2001), "İşletmelerde Yönetim Kurulunun Etkinliğini Sağlamada Denetim Komitelerinin Rolü”, Yaklaşım Dergisi, 12, 15-22.

BRSA (2019), Bă̆ımsız Denetim Kuruluşları, <https://www.bddk.org.tr/KuruluslarKategori/Bagimsiz-Denetim-Kuruluslari/10>, 05.07.2019.

Erol, A. \& A. Ertuğrul (2001), "Bankalarda Denetim-Tanımlar, Prensipler ve Bankacılık Düzenleme Kurulu ile İlişkiler”, Mükellefin Dergisi, 108, 210-229.

George, A. (1970), "The Market for Lemons: Quality under Uncertainty and the Market Mechanism", The Quarterly Journal of Economics, 84(3), 488-500.

Gündoğdu, A. (2016), Küresel Kriz Sonrası Gelişmeler Işı̆̆ında Bankacılı̆̆ın Temelleri, Nobel Yayınları, 1. Bask1, Ankara, Türkiye.

Güney, S. \& S.S. Sarı (2015), "Muhasebe Denetiminin Etkinliğini Sağlamada İç Kontrolün Rolü”, Sosyal Bilimler Enstitüsü Dergisi, 5, 99-124.

Humphrey, A. (2005), SWOT Analysis for Management Consulting, SRI International Alumni Newsletter.

INTOSAI (1998), The Lima Declaration of Guidelines on Auditing Precepts, Vienna, <http://www1.worldbank.org/publicsector/pe/befa05/LimaDeclaration.pdf >, 17.05.2019.

Learned, E.P. \& C.R. Christiansen \& K. Andrews \& W.D. Guth (1969), Business Policy: Text and Cases, McGraw Hill, USA.

Liggio, C.D. (1974), “The Expectation Gap: The Accountant's Waterloo”, Journal of Contemporary Business, 3, 27-44.

Litjens, R. \& J. van Buuren \& R. Vergoossen (2015), “Addressing Information Needs to Reduce the Audit Expectation Gap: Evidence from Dutch Bankers, Audited Companies and Auditors", International Journal of Auditing, 19(3), 267-281.

Mishkin, F.S. (1997), The Causes and Propagation of Financial Instability: Lessons for Policy Makers, <http://www.kc.frb.org/publicat/sympos/1997/pdf/s97mishk.pdf>, 10.05.2019.

Mishkin, F.S. (2009), “Is Monetary Policy Effective During Financial Crises?”, NBER Working Papers from National Bureau of Economic Research, No: 14678.

Müslümov, A. \& G. Aras (2004), "Kredi Piyasalarında Asimetrik Bilgi ve Bankacılık Sistemi Üzerindeki Etkileri”, İktisat, İsletme ve Finans Dergisi, 222, 55-65.

Oktay, S. (2013), "Bağımsız Denetim Etkinliğinin Artırılmasında Denetim Hizmetinde Kalite ve Kalite Kontrol, ABD Düzenlemeleri”, Maliye Finans Yazıları, 42-94.

Okur, Y. (2010), “Türkiye'de Teftiş ve İç Denetim: Kavramlar, Beklentiler ve Hayatla Yüzleşme”, Maliye Dergisi, 158, 570-586. 
Prinsloo, J. (2008), “The Development and Evaluation of Risk-Based Audit Approaches”, Magister in Accounting, Faculty of Economic and Management Sciences, University of the Free State.

Rioja, F. \& N. Valev (2004), "Finance and the Sources of Growth at Various Stages of Economic Development", Economic Inquiry, 42(1), 127-140.

Şahin, İ. (2012), "Türk Bankacılık Sisteminde Asimetrik Bilgi Sorununun Giderilmesine Yönelik Müşterinin Tanınmasını Sağlayıcı Ortak Veritabanı Uygulamaları”, Akademik Bakış Dergisi, 33, 1-18.

Siddiqui, J. \& J. Podder (2002), "Effectiveness of Bank Audit in Bangladesh", Managerial Auditing Journal, 17(8), $502-510$.

Stiglitz, J.E. \& A. Weiss (1981), “Credit Rationing in Markets with Imperfect Information”, The American Economic Review, 71(3), 393-410.

Yazıc1, M. (2015), Bankacılı̆̆a Giriş, Beta Yayınları, 3. Baskı, İstanbul, Türkiye. 
Sönmez-Özekicioğlu, S. \& F. Yetiz (2020), "External Audit and Asymmetric Information Problem: Alternative Framework in Public Banking", Sosyoekonomi, Vol. 28(46), 75-93. 